infants: the role of adults as reservoirs of infection. Am J Dis Child 1978;132:371-5.

2 Badr-el-din MK, Aref $\mathrm{GH}$, Mazloum $\mathrm{H}$, et al. The betaadrenergic receptors in pertussis. J Trop Med Hyg 1976;79: 213-7.

${ }^{3}$ Badr-el-din MK, Aref GH, Kassem AS, Abdel-Moneim MA, Abbassy AA. A beta-adrenergic stimulant, salbutamol, in the treatment of pertussis. J Trop Med Hyg 1976;79:218-9.
${ }^{4}$ Pittman M. The concept of pertussis as a toxin-mediated disease. Pediatr Infect Dis 1984:3:467-86.

${ }^{5}$ Lenney W, Milner AD. At what age do bronchodilator drugs work? Arch Dis Child 1978;53:532-5.

Correspondence to Dr A Y-C Tam, Department of Paediatrics, University of Hong Kong, Queen Mary Hospital, Hong Kong.

Received 5 February 1986

\title{
Nebulised ipratropium and salbutamol in asthma
}

\author{
J STORR AND W LENNEY
}

Royal Alexandra Hospital for Sick Children, Brighton

SUMmaRY Treatment with nebulised salbutamol or a mixture of salbutamol and ipratropium was given to 138 children. Length of hospital stay and number of nebulised doses required did not differ. In severe asthma response was greater with salbutamol alone. In mild asthma response was greater with combined treatment.

Ipratropium bromide is an effective bronchodilator in children. ${ }^{1-3}$ There are potential advantages in combining it with a beta adrenergic agent in treating asthma. ${ }^{2}$ We aimed to discover whether the addition of ipratropium to treatment with salbutamol would lead to a therapeutic response greater than that attainable with salbutamol alone.

\section{Patients}

All patients admitted to our hospital because of asthma between October 1984 and March 1985 were studied. There were 138 children, 95 boys and 43 girls. Their ages ranged from 11 months to 15 years, with a mean of 5.0 years. Thirteen were aged under 18 months. One hundred and five $(76 \%)$ had had one or more previous admissions for asthma.

\section{Methods}

The children were randomly allocated to a salbutamol or a combined treatment group. The former received $5 \mathrm{mg}$ salbutamol and the latter $5 \mathrm{mg}$ salbutamol mixed with $0.25 \mathrm{mg}$ ipratropium in each nebuliser. Nebuliser solutions were of equal tonicity and were administered double blind.

There were 70 patients in the salbutamol group and 68 in the combined treatment group. Standardised admission sheets were used, which incorpor- ated a score of clinical severity (scale: $0-10)$. The mean admission scores in each group were almost identical (4.69 and 4.52). The age and sex distribution were similar, as were the past history, family history, parental smoking history, and drugs used before admission.

Nebulisers were given within set limits at the discretion of the nursing staff. Steroids were given to children not responding satisfactorily to nebulised treatment, and intravenous aminophylline was given to children in severe respiratory distress.

In those old enough to produce accurate readings peak expiratory flow rates were measured immediately before and 20 minutes after treatment (except at night). Percentage changes in the peak expiratory flow rate were stratified so that responses were compared at similar degrees of severity. All statistics were analysed using the Wilcoxon rank sum method for unpaired data.

\section{Results}

Mean length of hospital stay and number of doses of nebulised medicine required were similar in each group (Table 1). Thirty five patients receiving

Table 1 Length of admission and treatment required in the two treatment groups

\begin{tabular}{lll}
\hline & Treatment group & \\
\cline { 2 - 3 } & Salbutamol & $\begin{array}{c}\text { Salbutamol and } \\
\text { ipratropium }\end{array}$ \\
\hline $\begin{array}{l}\text { No of patients } \\
\begin{array}{l}\text { Mean length of } \\
\text { admission (days) }\end{array}\end{array}$ & 70 & 68 \\
$\begin{array}{l}\text { Mean total no } \\
\text { of nebulisers given }\end{array}$ & $2 \cdot 8$ & 3.0 \\
$\begin{array}{l}\text { No treated with: } \\
\text { Steroids } \\
\text { Intravenous aminophylline }\end{array}$ & $8 \cdot 6$ & 9.3 \\
\hline & 1 & 19 \\
\hline
\end{tabular}


Table 2 Median percentage increase in peak expiratory flow rates in the two treatment groups related to degree of airways obstruction before treatment with nebulisers

\begin{tabular}{|c|c|c|}
\hline \multirow{2}{*}{$\begin{array}{l}\text { Degree of } \\
\text { airways } \\
\text { obstruction }\end{array}$} & \multicolumn{2}{|c|}{ Treatment group } \\
\hline & Salbutamol & $\begin{array}{l}\text { Salbutamol and } \\
\text { ipratropium }\end{array}$ \\
\hline Severe & 56 & 31 \\
\hline Moderate & 18 & 21 \\
\hline Mild & 5 & 10 \\
\hline
\end{tabular}

salbutamol and 32 receiving combined treatment had admission symptom scores of 5 or over, and in this severe group there was again no difference in response to the two treatments.

Only 39 patients ( 28 boys and 11 girls) were able to provide reproducible measurements of peak expiratory flow rates (17 salbutamol, 22 combined treatment). As gauged by the initial rate severity was similar in the two groups. The median length of hospital stay was three days in those receiving salbutamol and four days in those receiving combined treatment. The median values for the number of nebulised doses received per patient were 10 and 12. These differences were not significant.

Airway obstruction before each nebuliser dose was classified as severe, moderate, or mild according to the percentage reduction in values of peak expiratory flow rate $(<50 \%, 50 \%-74 \%, \geqslant 75 \%)$, and mean peak expiratory flow rate responses were compared within these strata. The 23 children who initially had severe airways obstruction were evenly distributed between the treatment groups. Severe airways obstruction responded significantly better to salbutamol alone $(p=0.007)$, whereas mild airways obstruction responded better to combined treatment $(p=0.033)$; moderate airways obstruction showed little difference in response to either treatment (Table 2). The trend for severe airways obstruction to respond better to salbutamol alone was not seen in the 14 children whose parents were smokers.

\section{Discussion}

No differences have been shown in the length of hospital stay or number of nebuliser doses required in children receiving nebulised salbutamol or combined salbutamol and ipratropium. In those children able to provide measurements of peak expiratory flow rate differences became apparent in that those with severe airways obstruction responded less well initally to combined treatment.

Inhaled anticholinergic agents have previously been found to be less effective during acute exacerbations of asthma than in the same patients during remission. ${ }^{4}$ This may reflect the decreased relative contribution of vagal tone to airway resistance during exacerbations of asthma. Our study suggests, however, that in severe asthma ipratropium may antagonise the action of salbutamol.

Ipratropium preferentially dilatates larger airways, and this might alter the intraluminal pressure gradient during forced expiration, resulting in earlier closure of small airways. An effect on mucus clearance cannot be excluded; ipratropium has been shown not to impair mucociliary clearance in adults with bronchitis, ${ }^{5}$ but this finding cannot be extrapolated to the small airways and viscid mucus of young asthmatic patients. Altounyan postulated a delayed effect on membrane permeability to account for a similar variation in the effect of anticholinergic agents on smooth muscle tone in vitro, the effect varying with local concentrations of histamine. ${ }^{4}$

Whatever the explanation, we cannot recommend the addition of ipratropium to treatment regimens in acute severe childhood asthma.

We thank Dr Evans and Dr Hatcher for the use of their patients, Mr R Herbert who prepared the solutions, and the nursing staff of Taaffe ward. JS was supported by a grant from the RAH Centenary Fund.

\section{References}

1 Mann NP, Hiller EJ. Ipratropium bromide in children with asthma. Thorax 1982;37:72-4.

2 Groggins RC, Milner AD, Stokes GM. Bronchodilator effects of clemastine, ipratropium bromide, and salbutamol in preschool children with asthma. Arch Dis Child 1981;56:342-4.

${ }^{3}$ Hodges ICG, Groggins RC, Milner AD, Stokes GM. Bronchodilator effect of inhaled ipratropium bromide in wheezy toddlers. Arch Dis Child 1981;56:729-32.

4 Altounyan REC. Variation of drug action on airway obstruction in man. Thorax 1964;19:406-15.

5 Pavia D, Bateman JRM, Sheahan N, Clarke SW. Effect of ipratropium bromide on mucociliary clearance and pulmonary function in reversible airways obstruction. Thorax 1979;34: 501-7.

Correspondence to Dr W Lenney, Royal Alexandra Hospital for Sick Children, Dyke Road, Brighton BN1 3JN, England.

Received 6 March 1986 